\title{
ADDITIVE INTERCROPPING WITH LEGUME CROPS INCREASES WAXY MAIZE YIELD ON VERTISOL RICELAND IN LOMBOK, INDONESIA
}

\author{
Wangiyana Wayan ${ }^{1 *}$, Irwinsyah Lalu Rahmadi ${ }^{2}$, Parawinata $^{3}$, Kisman $^{1}$ \\ ${ }^{1}$ Faculty of Agriculture, University of Mataram (Unram), Indonesia \\ ${ }^{2}$ BKPPP Office of Central Lombok Regency, Indonesia \\ ${ }^{3}$ Agriculture and Veterinary Service Office of Central Lombok Regency, Indonesia \\ *E-mail: w.wangiyana@unram.ac.id
}

\begin{abstract}
Central Lombok Regency (Indonesia) is dominated by vertisol soil, where irrigated or rainy season rice crop is normally rotated with non-rice food crops during the dry season, and to minimize risks of failure, multiple-cropping systems are normally established. This research aimed to examine the effects of additive intercropping, by inserting 1-3 rows of mungbean or soybean between rows of waxy maize on the vertisol riceland. The experiment was designed with Split-Split Plot Design with three bocks and three treatment factors, i.e. types of legume crops (mungbean or soybean) as the main plots, additive intercropping (insertion of $0,1,2$ or 3 rows of legume crops between maize rows) as the sub-plots, and doses of $\mathrm{N}$ fertilizer for waxy maize (full or half the recommended dose) as the sub-sub-plots. Results indicated that intercropping waxy maize with legume crops increased maize leaf $\mathrm{N}$ concentration and uptake, leaf $P$ uptake, number of green leaves at 6 and 7 weeks after seeding, ear and shoot dry weight, plant height, and grain yield of the waxy maize. Reduction of maize $\mathrm{N}$ doses also reduced maize grain yield. However, there was a significant interaction between intercropping and $\mathrm{N}$ doses, in which reduction of maize $\mathrm{N}$ doses to $50 \%$ of the recommended doses did not reduce maize grain yield in the maize plants intercropped with 1 or 2 rows of legume crops but this treatment significantly reduced maize grain yield in the monocrop or in intercropping with 3 rows of legume crops. Therefore, insertion of 1-2 rows of legume crops between rows of waxy maize increases land productivity since the legume crops also produced seeds and biomass that can be used as cattle feed. Between the legume crops, intercropping with soybean was better than mungbean in increasing the waxy maize grain yield.
\end{abstract}

\section{KEY WORDS}

Additive intercropping, mungbean, soybean, waxy maize, nitrogen uptake.

Waxy maize or glutinous maize or waxy corn is one type of specialty corns. Its endosperm can contain nearly $100 \%$ amylopectin or without amylose (White, 2001). In the US, waxy maize was produced through hybridization, and according to Fergason (2001), waxy corn starch is commercially used in various industries, such paper making, adhesives, and food industries. Waxy corn is also much better than the normal dent corn in fattening various types of livestock, such as in lamb fattening (Fergason, 2001). In Indonesia, besides for use in food industry, waxy corn is also harvested as green ears to be consumed as boiled or steamed corn seeds like sweet corn. For food, maize grains contain nutrition and crude fiber needed by the human body, including fats, protein, crude fiber and carbohydrates, and minerals such as sodium, $\mathrm{K}, \mathrm{Ca}, \mathrm{Fe}, \mathrm{Zn}, \mathrm{Mg}$ and $\mathrm{Cu}$ (Ullah et al., 2010). Maize kernels also contain various vitamins such as Thiamin, Riboflavin, Niacin, Pantothenic acid, and vitamin B6 (Gwirtz and Garcia-Casal, 2014).

In Indonesia, there are many types of maize varieties, including hybrids, national superior varieties, and local varieties. One of the local varieties widely cultivated in the West Nusa Tenggara (NTB) province, Indonesia, is the waxy maize of "Bima" local variety. Waxy corn is getting popular, because it tastes good, more savory, and softer than other types of maize due to its very high content of amylopectin. However, the productivity of this maize is low compared with that of hybrid maize, especially if no adequate fertilizers are applied 
(Azrai et al., 2007). Zingore (2011) also reported that application of fertilizers significantly increase maize productivity in the sub-Saharan Africa, in which without fertilizer, grain yield was very low, i.e. only $0.8 \mathrm{t} / \mathrm{ha}$, but increased to $3.8 \mathrm{t} / \mathrm{ha}$ with $\mathrm{N}$, and $4.3 \mathrm{t} / \mathrm{ha}$ with manure + $\mathrm{N}$ fertilizer, even in medium soil fertility. However, management of cropping system can also increase maize productivity, as reported by Zingore (2011), where fertilized maize grown following groundnut yielded $5.9 \mathrm{t} / \mathrm{ha}$ compared with only $4.4 \mathrm{t} / \mathrm{ha}$ in continuous maize.

In addition, intercropping cereal with legume crops can also increase grain yield of the cereal crops, as reported by Wangiyana and Kusnarta (1998) that waxy maize grown on entisol ricefield following rice crop produced higher seed yield and higher $\mathrm{N}$ uptake in intercropping with legume crops, especially mungbean or peanut, compared with in the maize monocroppping system. Yilmaz et al. (2008) also showed higher grain yield of maize intercropped with common bean or cowpea than maize in the sole cropping system. Increased seed yield, dry weight and/or $\mathrm{N}$ uptake by cereal crops also accurred in sorghum intercropped with soybeans (Ghosh et al., 2006). By using radio-isotope techniques, some researchers have proven some transfer of $\mathrm{N}$ from legumes to adjacent non-legume crops through hyphae of arbuscular mycorrhizal fungi (AMF) infecting roots of both types of plants (Bethlenfalvay et al., 1991; Hamel et al., 1991).

This research reports the effects of additive intercropping of waxy maize of "Bima" local variety, by inserting 1-3 rows of mungbean or soybean, on $N$ and $P$ uptake, growth, and yield of the waxy maize grown on a ricefield of vertisol soil type in Central Lombok, Indonesia.

\section{MATERIALS AND METHODS OF RESEARCH}

Design of the experiment. The field experiment was conducted during the dry season II, after harvest of the dry season I rice crop, on a farmer's paddyfield in Mujur village of Central Lombok (Indonesia), with vertisol soil type. The experiment was arranged according to Split-Split Plot design with three blocks and three treatment factors, i.e. types of legume crops ( $\mathrm{L} 1=$ mungbean or $\mathrm{L} 2=$ soybean) as the main plots; additive intercropping treatments [by insertion of 0 (ML0), 1 (ML1), 2 (ML2) or 3 (ML3) rows of legumes between two rows of maize] as the sub-plots; and doses of $\mathrm{N}$ fertilizer $(\mathrm{N} 1=$ full or $\mathrm{N} 2=$ half dose of Urea applied to maize plants only) as the sub-sub-plots. The full $\mathrm{N}$ dose was the recommended dose for non-hybrid maize (300 kg/ha Urea).

Implementation of the experiment. After tillage, the land was split into three blocks; each block was split into two main plots; each main plot was split into four sub-plots; and each sub-plot was split into two sub-sub-plots. Therefore, there were 48 treatment plots of raised beds of $3.2 \mathrm{~m} \times 2.0 \mathrm{~m}\left(6.40 \mathrm{~m}^{2}\right)$ each, separated with furrows of $50 \mathrm{~cm}$ width and $15 \mathrm{~cm}$ depth.

Seeds of the waxy maize of the "Bima" local variety (3-4 seeds) were dibbled at $40 \mathrm{~cm}$ within and $80 \mathrm{~cm}$ between rows. Seeds of mungbean (Vigna radiata (L) Wilczek cv. "Vima-1") or soybean (Glycine max (L) Merr cv. "Grobogan") were dibbled (3-4 seeds) between rows of maize plants by seeding $0,1,2$, or 3 rows of legume seeds, depending on the treatments, at $20 \mathrm{~cm}$ within and between rows of legume plants. After 7 days they were tinned by leaving to grow 2 maize or legume plants per hill (or planting hole).

Maize plants was fertilized using Urea $(45 \% \mathrm{~N})$, triple super phosphate (TSP), and $\mathrm{KCl}$ fertilizers, with the recommended dose of $300,100,100 \mathrm{~kg} / \mathrm{ha}$, respectively. All amounts of TSP and $\mathrm{KCl}$ were mixed together with $1 / 3$ treatment dose of Urea, and were banded (dibbled) $5 \mathrm{~cm}$ beside the young maize plants at $5 \mathrm{~cm}$ depth at one week after seeding (WAS), i.e. after tinning. The rest of Urea was dibbled at 3 and 6 WAS at 1/3 treatment dose, each. To the mungbean or soybean plants no fertilizers were applied. Weeding and irrigation were done as necessary. The maize dry ears were harvested at 75 DAS.

Observation variables and data analysis. Maize variables were measured on four clumps of permanent samples and two clumps of destructive samples, taken from the plants around the center of the plots excluding the outer-most plants on the plots. The destructive samples were harvested at 6 WAS for leaf, ears, and total shoot dry weight, and leaf total-N and total-P concentrations, while the permanent samples were used to measure dry grain 
yield, and plant height and green leaf number every week from 2 to 7 WAS, but only the last measurement results were analyzed. Dry grain yield and dry stover weights per clump of four samples and per plot of the legume crops were also measured. $N$ and $P$ uptake in the maize leaves were calculated by multiplying leaf dry weight at 6 WAS with total-N and total-P concentrations of the leaves. Data were analyzed using analysis of variance (ANOVA) and Least Significant Difference (LSD) test for means differences, both at $5 \%$ significance level, using CoStat for Windows ver. 6.303, after conducting pre-analysis for normality of the data using Minitab for Windows Rel. 13.0.

\section{RESULTS AND DISCUSSION}

Based on the normality test, the shoot dry weight of the destructive samples, and $P$ uptake were not normally distributed, but when those were transformed into $\sqrt{ } \mathrm{x}$, they become normally distributed. The ANOVA results, summarized in Table 1, show that the interaction effects are significant only on several observation variables measured on waxy maize crop, i.e. on ear and total dry weight at 6 WAS, green leaf numbers at 6 and 7 WAS, and dry grain yield per clump. In terms of the main effects of each treatment factor, types of legume crops (L) inserted between rows of waxy maize significantly affected ear and shoot dry weight, maize plant height and grain yield per clump, which were higher on waxy maize intercropped with soybean than with mungbean (Table 2 and Table 3). Among the treatment factors tested, intercropping showed significant effects on all observation variables except on leaf dry weight at 6 WAS and leaf total-P concentration, while doses of $\mathrm{N}$ fertilizer only significantly affected numbers of green leaves at 6 and 7 WAS, leaf total-N concentration and $\mathrm{N}$-uptake, and maize grain yield per clump (Table 1).

The significant main effects, summarized in Table 2, indicate that in terms of $\mathrm{N}$ and $\mathrm{P}$ nutrition of the waxy maize plants, leaf total- $\mathrm{N}$ concentration and $\mathrm{N}$-uptake were significantly different between $\mathrm{N}$ doses, i.e. higher in the full $\mathrm{N}$ than in the half $\mathrm{N}$ doses, whereas $\mathrm{P}$ uptake and leaf total-P concentration (Table 2) were not significantly different between $\mathrm{N}$ doses. However, between the intercropping treatments, $\mathrm{N}$ uptake was significantly different, i.e. highest in the leaves of maize plants intercropped with two rows of legume crops (ML2 treatment). It is possible that the additional $\mathrm{N}$ was obtained from rhizosphere of the legume crops, since mungbean and soybean can establish biological nitrogen fixation (BNF) in symbiosis with Rhizobium bacteria. Many researchers have previously reported that better $\mathrm{N}$ nutrition of cereal crops in a legume-cereal intercropping compared with in cereal monocropping system is due to transfer of $\mathrm{N}$ from rhizosphere of legume to non-legume crops (Bethlenfalvay et al., 1991; Hamel et al., 1991; Ghosh et al., 2006). Higher N concentration of the rhizosphere of maize plants intercropped with legume crops than that of monocropped maize plants has also been reported (Wangiyana and Kusnarta, 1998; Yilmaz et al., 2008).

Table 1 - Summary of the ANOVA results of the main and interaction effects for all observation variables of the waxy maize crop

\begin{tabular}{|c|c|c|c|c|c|c|c|}
\hline \multirow{2}{*}{ Observation variables } & \multicolumn{3}{|c|}{ Main effects } & \multicolumn{4}{|c|}{ Interaction effects } \\
\hline & Legume (L) & Additive intercrop ( $\mathrm{Ai})$ & N Dose & $L x A$ & $\mathrm{LxN}$ & $\mathrm{AxN}$ & LxAxN \\
\hline Leaf dry weight 6 WAS & ns & ns & ns & ns & ns & ns & ns \\
\hline Ear dry weight 6 WAS & ** & * & ns & ns & ns & * & ns \\
\hline Total shoot dry weight 6 WAS & * & * & ns & ns & ns & * & ns \\
\hline Green leaf number 6 WAS & ns & * & * & * & * & ns & ns \\
\hline Green leaf number 7 WAS & ns & * & ** & * & * & ns & $\star \star$ \\
\hline Maximum plant height (7 WAS) & ** & ** & ns & ns & ns & ns & ns \\
\hline Leaf total-P concentration (\%) & ns & ns & ns & ns & ns & ns & ns \\
\hline Leaf total-N concentration (\%) & ns & * & ** & ns & ns & ns & ns \\
\hline$P$ uptake in the leaves $(\mathrm{mg})^{\# \prime}$ & ns & * & ns & ns & ns & ns & ns \\
\hline $\mathrm{N}$ uptake in the leaves (mg) $\#$ & ns & ** & ** & ns & ns & ns & ns \\
\hline Dry grain yield per clump (g) & * & * & $\star * *$ & $* * *$ & ns & $\star *$ & ns \\
\hline
\end{tabular}

Note: $n s=$ non-significant; ${ }^{*}$ and ${ }^{* *}=$ significant at $p$-value $<0.05$ and $<0.01$; ${ }^{\#)}$ data were transformed to $\sqrt{ } x$. 
Table 2 - Mean values of leaf $\mathrm{P}$ and $\mathrm{N}$ contents (\%), $\mathrm{P}$ and $\mathrm{N}$ uptake $(\mathrm{mg} / \mathrm{clump})$, and dry grain yield ( $\mathrm{g} / \mathrm{clump}$ ) of waxy maize under various treatments ( $\mathrm{N}$ doses, additive intercropping with legumes, and types of legume crops)

\begin{tabular}{|c|c|c|c|c|c|c|c|c|c|c|}
\hline $\begin{array}{c}\text { Treatmen } \\
\text { ts: }\end{array}$ & $\begin{array}{r}\text { Leaf t } \\
(\%\end{array}$ & & $\begin{array}{r}\text { Leaf } t \\
(9 \\
\end{array}$ & & $\begin{array}{l}\text { Leaf } P \text { uptak } \\
\text { (mg/clump) }\end{array}$ & & $\begin{array}{l}\text { Leaf } \mathrm{N} \text { upta } \\
\text { (mg/clump) }\end{array}$ & & $\begin{array}{r}\text { Maize gr } \\
(\mathrm{g} / \mathrm{clc}\end{array}$ & \\
\hline $\mathrm{Ndo}$ & & & & & & & & & & \\
\hline N1 (full) & 1.04 & a & 1.26 & $\mathrm{a}$ & $304.2(17.44)$ & $\mathrm{a}$ & 374.0 (19.34) & $\mathrm{a}$ & 112.71 & $a^{2)}$ \\
\hline N2 (half) & 1.03 & a & 1.10 & b & $287.8(16.97)$ & $\mathrm{a}$ & $310.8(17.63)$ & b & 101.35 & $b$ \\
\hline LSD 5\% & 0.23 & & 0.11 & & (1.94) & & $(1.04)$ & & 4.97 & \\
\hline & ditive ir & $\mathrm{cro}$ & ping: & & & & & & & \\
\hline MLO & 0.95 & a & 1.12 & b & 260.7 (16.15) & b & 315.5 (17.76) & $\mathrm{bc}$ & 103.13 & b \\
\hline ML1 & 1.14 & a & 1.19 & $a b$ & 336.3 (18.34) & $\mathrm{a}$ & $351.2(18.74)$ & b & 106.04 & b \\
\hline ML2 & 1.13 & a & 1.31 & $\mathrm{a}$ & 338.9 (18.41) & $\mathrm{a}$ & 397.7 (19.94) & a & 112.71 & a \\
\hline ML3 & 0.91 & $\mathrm{a}$ & 1.09 & $\mathrm{~b}$ & 253.6 (15.92) & b & 306.0 (17.49) & $\mathrm{c}$ & 106.25 & b \\
\hline LSD $5 \%$ & 0.24 & & 0.15 & & (2.04) & & (1.06) & & 5.32 & \\
\hline$\overline{\text { Legume }}$ & becies: & & & & & & & & & \\
\hline Mungbea & 1.08 & a & 1.23 & $\mathrm{a}$ & 276.3 (16.62) & $\mathrm{a}$ & 322.8 (17.97) & a & 100.63 & b \\
\hline $\begin{array}{l}\text { Soybean } \\
\text { LSD 5\% }\end{array}$ & $\begin{array}{l}0.99 \\
0.52\end{array}$ & a & $\begin{array}{l}1.12 \\
0.26\end{array}$ & $\mathrm{a}$ & $\begin{array}{c}316.4(17.79) \\
(2.40)\end{array}$ & $\mathrm{a}$ & $\begin{array}{c}361.1(19.00) \\
(1.71)\end{array}$ & $\mathrm{a}$ & $\begin{array}{c}113.44 \\
6.06\end{array}$ & $\mathrm{a}$ \\
\hline
\end{tabular}

Note: $:^{1)}$ For ANOVA and mean comparisons using LSD test, data were transformed into $\sqrt{ } x$ with their averages and LSD values are in the brackets; ${ }^{2)}$ Mean values in each column of a variable followed by the same letters are not significantly different between levels of a treatment factor (main effects).

Number of green leaves at 6 and 7 WAS (Table 3) was also higher in maize plants receiving full (N1) than half $\mathrm{N}(\mathrm{N} 2)$ doses, indicating a faster reduction in the average number of green leaves in the $\mathrm{N} 2$ than $\mathrm{N} 1$ treatment. This could be due to a faster $\mathrm{N}$ remobilization from leaves to the developing maize seeds in N2 treatment, possibly due to less dose of Urea $(\mathrm{N})$ application to the maize plants. These all may be related to leaf chlorophyll contents, as also reported by Rashid et al. (2005) that maize leaf $\mathrm{N}$ contents at $6^{\text {th }}$ leaf growth stage are closely related to chlorophyll meter readings; and these readings were closely related to nitrate- $\mathrm{N}$ contents in the rhizosphere of the maize plants. Leaves of the waxy maize plants intercropped with legume crop (i.e. mungbean) in this field experiment were also greener than those in the monocropped maize plants at 6 WAS, which could be an indication of higher chlorophyll contents in leaves of the intercropped waxy maize (Figure 1). Inal et al. (2007) also reported that leaves of maize plants intercropped with peanut contain significantly higher chlorophyll than maize plants in the monocropping system.

Table 3 - Mean values of growth components of waxy maize under various treatments ( $\mathrm{N}$ doses, additive intercropping with legumes, and types of legume crops)

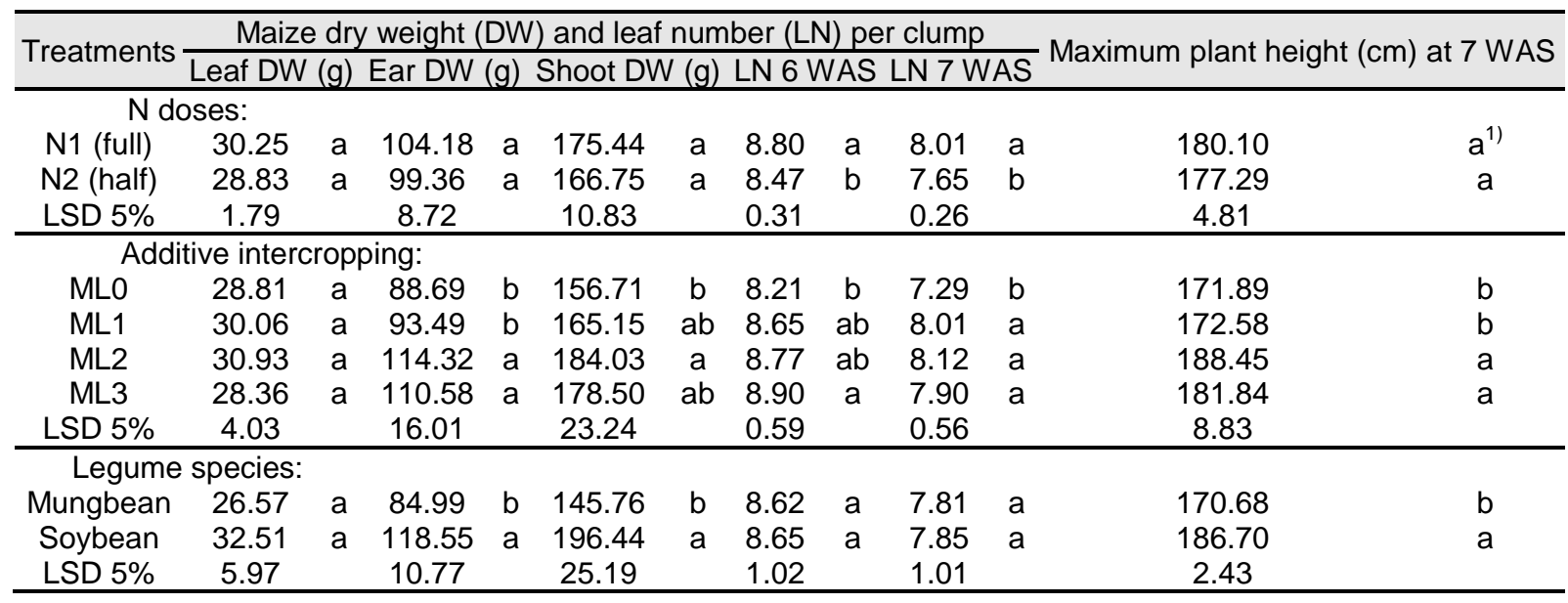

Note: ${ }^{1)}$ Mean values in each column of a variable followed by the same letters are not significantly different between levels of a treatment factor (main effects). 
Although there was a significant effect of intercropping the waxy maize plants with the legume crops (Table 1), average $\mathrm{N}$ uptake in the leaves of the waxy maize was higher only on the ML1 and ML2 treatments, while between MLO and ML3, there was no differences, and the average was lowest in the ML3 treatment, and significantly lower than the average in the ML1 and ML2 treatments (Table 2).
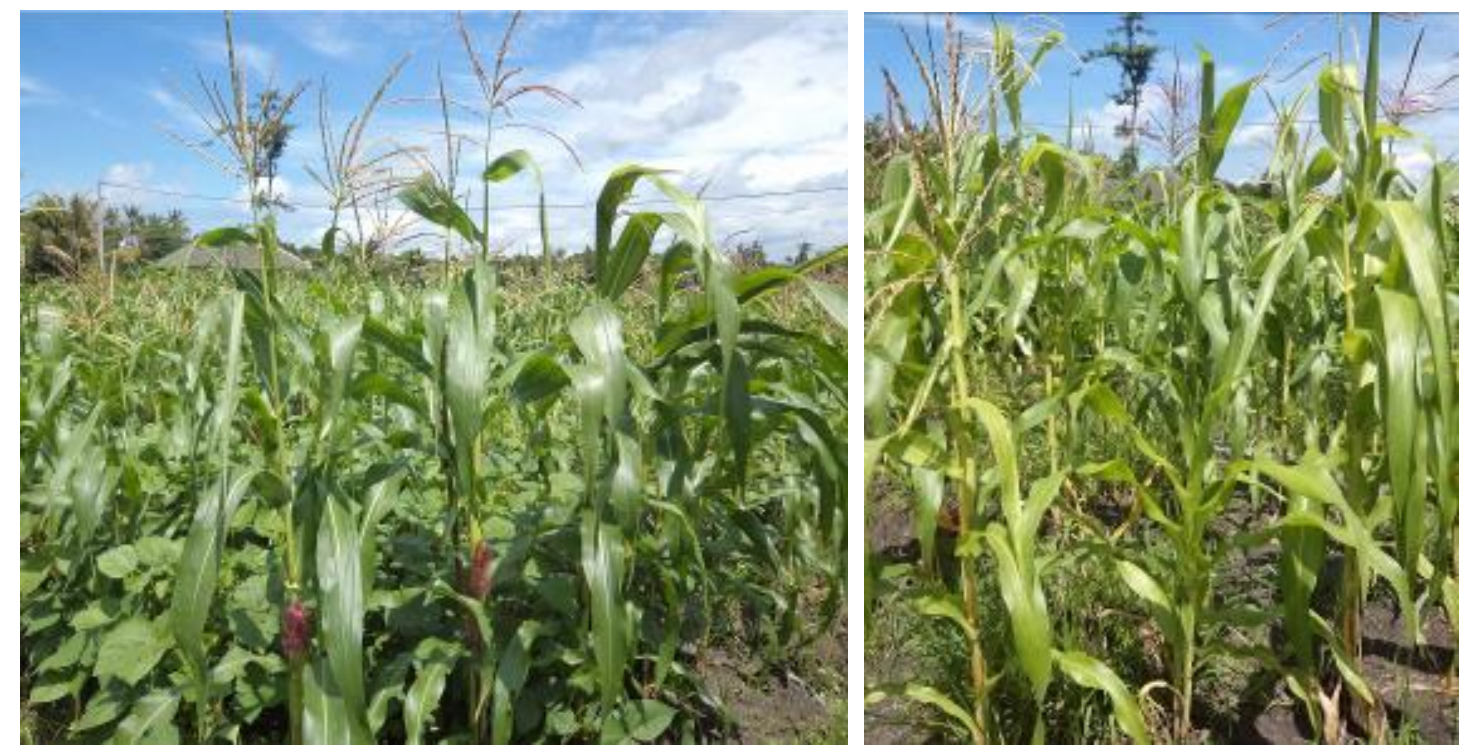

Figure 1 - Performance of the waxy maize plants growing on the treatment of maize additive intercropped with 2 rows of mungbean (Left) compared with the maize plants growing on the monocrop (Right), in which leaves of the waxy maize plants were greener in the intercropping than in the monocrop treatment

Table 4 - Mean and SE values of dry grain yield and dry stover weight per plot, and dry seed and dry stover weight per clump for the legume crops inserted between rows of maize

\begin{tabular}{|c|c|c|c|c|c|c|c|c|}
\hline \multirow{2}{*}{$\begin{array}{l}\text { Legume } \\
\text { crops }\end{array}$} & \multirow{2}{*}{$\begin{array}{l}\text { Inter- } \\
\text { cropping }\end{array}$} & \multirow[t]{2}{*}{ N-doses } & \multicolumn{2}{|c|}{$\begin{array}{c}\text { Legume dry grain yield } \\
\text { (g/plot) }\end{array}$} & \multicolumn{2}{|c|}{$\begin{array}{l}\text { Legume dry stover weight } \\
\text { (g/plot) }\end{array}$} & \multicolumn{2}{|c|}{$\begin{array}{l}\text { Legume dry weight } \\
\text { (g/clump) }\end{array}$} \\
\hline & & & Mean & SE & Mean & SE & Grains & Stover \\
\hline \multirow{6}{*}{ Mungbean } & \multirow{2}{*}{ ML1 } & N1(full) & 341.7 & 4.4 & 1207.7 & 26.6 & 11.39 & 40.26 \\
\hline & & N2(half) & 286.7 & 4.4 & 994.7 & 49.9 & 9.56 & 33.16 \\
\hline & \multirow{2}{*}{ ML2 } & N1(full) & 373.3 & 14.2 & 1344.0 & 27.6 & 6.22 & 22.40 \\
\hline & & N2(half) & 321.7 & 10.9 & 1093.7 & 37.2 & 5.36 & 18.23 \\
\hline & \multirow{2}{*}{ ML3 } & N1(full) & 415.0 & 5.8 & 1581.3 & 13.3 & 4.61 & 17.57 \\
\hline & & N2(half) & 346.7 & 18.6 & 1261.3 & 93.6 & 3.85 & 14.01 \\
\hline \multirow{6}{*}{ Soybean } & \multirow{2}{*}{ ML1 } & N1(full) & 460.0 & 23.1 & 1301.0 & 15.3 & 15.33 & 43.37 \\
\hline & & N2(half) & 453.3 & 17.6 & 1371.0 & 21.1 & 15.11 & 45.70 \\
\hline & \multirow{2}{*}{ ML2 } & N1(full) & 586.7 & 8.8 & 1441.0 & 26.9 & 9.78 & 24.02 \\
\hline & & N2(half) & 486.7 & 32.8 & 1324.3 & 59.0 & 8.11 & 22.07 \\
\hline & \multirow{2}{*}{ ML3 } & N1(full) & 633.3 & 8.8 & 1960.7 & 81.4 & 7.04 & 21.79 \\
\hline & & N2(half) & 560.0 & 15.3 & 1712.0 & 7.4 & 6.22 & 19.02 \\
\hline
\end{tabular}

Note: ML1, ML2, ML3 = maize-legume additive intercropping by inserting 1, 2 or 3 rows of legume crop between rows of maize; $N 1$ = full, $N 2$ = half $N$ dose; $S E$ = standard error .

This occurred possibly due to a higher degree of competition for $\mathrm{N}$ between maize and legume plants as well as between the legume plants in the ML3 treatments. The higher legume population in the ML3 than ML1 or ML2 treatment due to additional 27 clumps (1 row) of legume plants in the ML3 treatment could cause more competion for N in the ML3 than in the ML2 and ML1 treatments, especially during pod setting and seed-filling periods, because legume plants were not fertilized. According to Sinclair and de Wit (1975), legume crops such as soybean and mungbean often remobilize their leaf $\mathrm{N}$ to the growing seeds when root $\mathrm{N}$ uptake is not sufficient. Thus, when there is a higher competition for $\mathrm{N}$ due to 
higher legume population in the ML3 treatment, it would be possible that $\mathrm{N}$ uptake is lower in leaves of maize intercropped with 3 rows compared with only 1 or 2 rows of legume crops. Another indication of competition is the lower average of biomass weight and dry grain yield per clump of the legume crops in the treatments with higher number of rows of legume plants inserted between rows of waxy maize plants (Table 4).

Like $\mathrm{N}$ uptake, $\mathrm{P}$ uptake in the leaves of the waxy maize was also significantly different between intercropping treatments. In relation to intercropping maize with legume crop, Inal et al. (2007) also reported a significantly higher $P$ concentration of maize plant intercropped with peanut than maize plant in monocropping system. In this research, there was also a tendency of higher $\mathrm{P}$ uptake in the leaves of the waxy maize plants intercropped with soybean and mungbean although they were not significantly different (Table 2). However, shoot dry weight (Table 3 ) and grain yield per clump of the waxy maize (Table 2) were significantly different between the two types of legume crops, in which intercropping with soybean resulted in higher grain yield of the waxy maize compared with intercropping with mungbean plants. This means that soybean is better than mungbean in improving $P$ nutrition, shoot dry weight, and grain yield per clump of the waxy maize in the intercropping systems.

In terms of the main effects of those treatment factors on grain yield of the waxy maize, it can be seen from Table 2 that grain yield per clump was higher on the waxy maize plants intercropped with the legume crops compared with those in the monocrop treatment, especially those intercropped with two rows of legume plants. Unfortunately, based on the main effect, reduction in $\mathrm{N}$ dose of maize to half recommended dose significantly reduced maize grain yield. Nevertheless, there were significant interaction effects between intercropping and $\mathrm{N}$ doses of maize. Based on the interaction effects, it can be seen from Figure 2 that, when the waxy maize plants were not intercropped (ML0) or intercropped with 3 rows (ML3) of legume plants, reducing doses of $\mathrm{N}$ fertilizer to $50 \%$ of the recommended doses significantly reduced maize grain yield, while on the waxy maize plants intercropped with 1 or 2 rows of legume plants, reduction of the $\mathrm{N}$ doses did not reduce maize grain yield, but in fact it tended to increase the grain yield. This indicates some $\mathrm{N}$ contribution by the legume crops to the waxy maize in the intercropping although this needs further careful investigation. However, by using isotope technology, previous investigations have proven this kind of $\mathrm{N}$ transfer between legume and cereal crops in an intercropping system involving mycorrhizal fungi (Bethlenfalvay et al., 1991; Hamel et al., 1991).

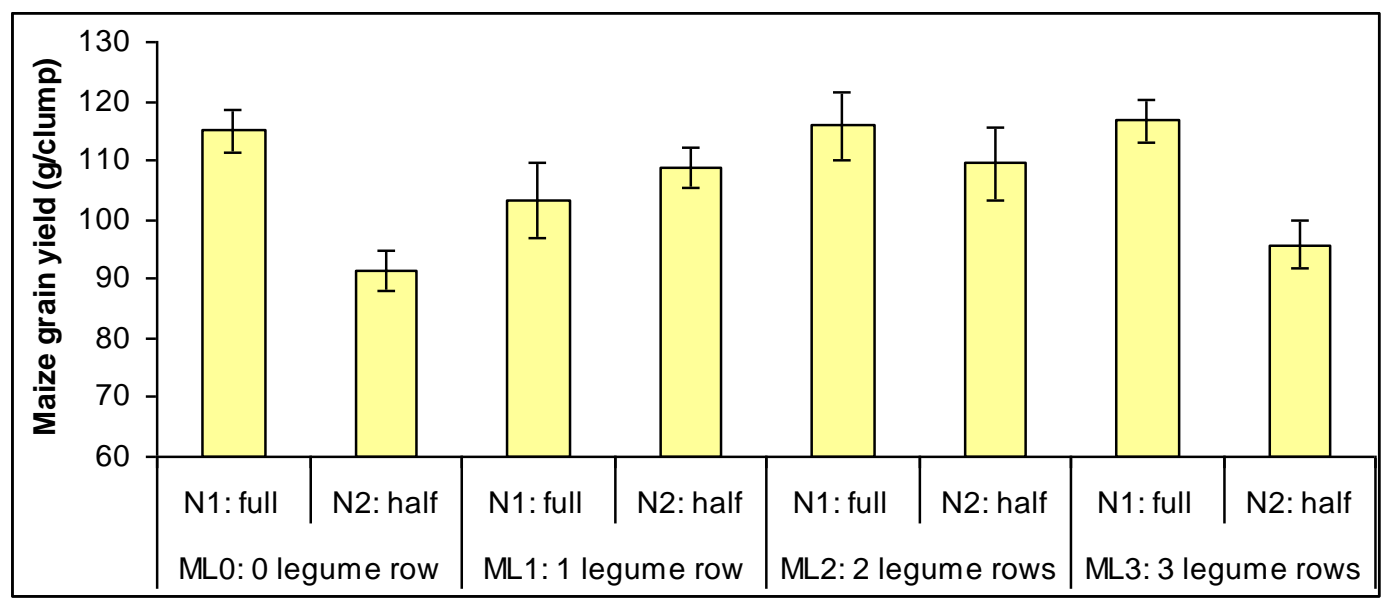

Figure 2 - Average (Mean $\pm \mathrm{SE}$ ) dry grain yield of waxy maize ( $\mathrm{g} / \mathrm{clump}$ ) as affected by interaction between additive intercropping with legume crops and doses of $\mathrm{N}$ fertilizer applied to maize

In addition, there was also a significant interaction between intercropping and types of legume crops inserted between maize rows, and it can be seen from Figure 3.A that between the two legume crops, intercropping with soybean resulted in higher grain yield of the waxy maize compared with intercropping with mungbean, indicating that soybean is better than mungbean in this case. This could be related to the tendency for the better 
$\mathrm{P}$ nutrition of the waxy maize plants intercropped with soybean than with mungbean, especially in the waxy maize plants intercropped with 2 rows of legume plants (Fig. 3.B).
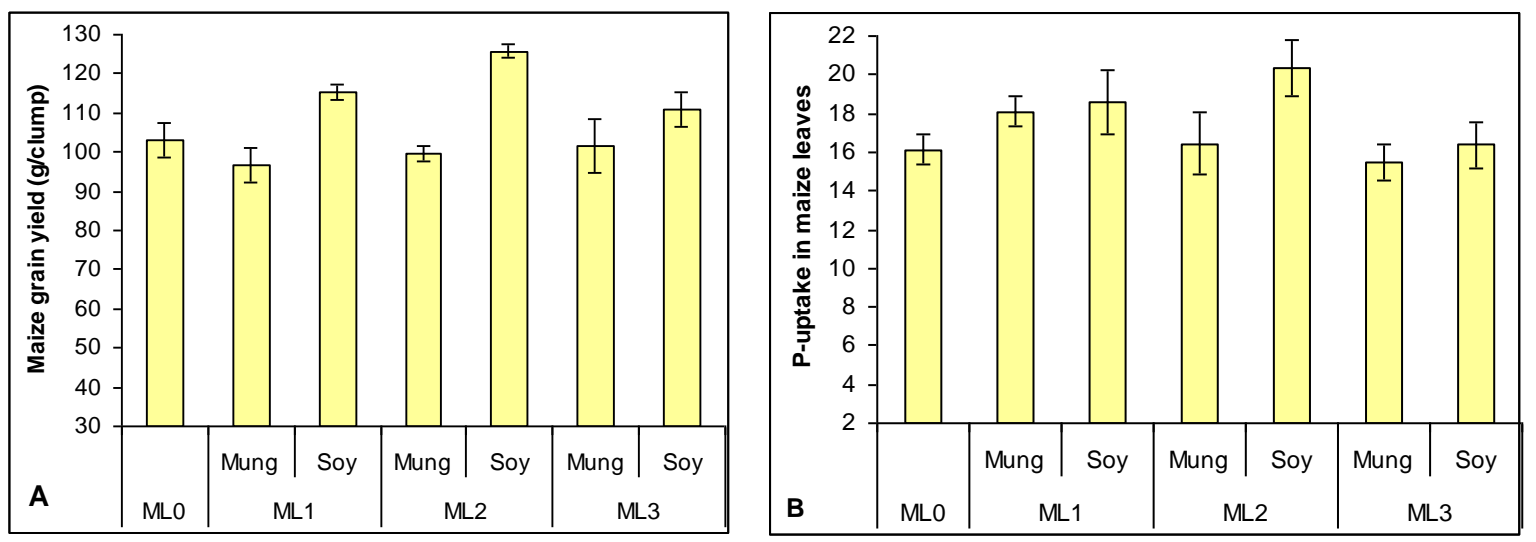

Figure 3 - Average (Mean $\pm \mathrm{SE}$ ) dry grain yield (g/clump) of waxy maize $[\mathrm{A}]$, and P-uptake (mg.P per clump, transformed to $\sqrt{ } \mathrm{x}$ ) in the maize leaves $[\mathrm{B}]$, as affected by interaction between additive intercropping with legume crops and doses of $\mathrm{N}$ fertilizer applied to maize

In addition to higher grain yield of the waxy maize intercropped with legume crops compared with those on the monocrop treatment, the legume crops inserted between maize rows also produced seeds as well as plant biomass (Table 4), which can be used as cattle feed. Therefore, it also means that additive intercropping with legume crops increased land productivity. However, because the legume crops were not fertilized, their grain yields per area unit were low (less than 1 ton/ha). In addition, the plots were not fully planted with the legume crops, i.e. no legume plants were grown on the outer lines of the maize plants on the plots.

\section{CONCLUSION}

It be concluded that additive intercropping of waxy maize of Bima local variety by inserting 1-3 rows of legume crops significantly increased dry grain yield of the waxy maize, and land productivity, and insertion of two rows of legume crops between rows of the waxy maize resulted in the highest $\mathrm{N}$ and $\mathrm{P}$ uptake in maize leaves as well as maize grain yield per clump. However, there was a significant interaction between intercropping and $\mathrm{N}$ doses, in which reduction of $\mathrm{N}$ fertilizer to $50 \%$ of the recommended $\mathrm{N}$ doses did not reduce maize grain yield per clump in the maize plants intercropped with 1 or 2 rows of legume crops but this treatment significantly reduced grain yield of maize plants in the monocrop or in those intercropped with 3 rows of legume crops.

\section{ACKNOWLEDGEMENTS}

The data reported here are results of combining two Split Plot Thesis Experiments, i.e. one by Parawinata (mungbean) and one by L.R. Irwinsyah (soybean); the first and the last authors were the supervisors, but the treatment design was from the first author.

\section{REFERENCES}

1. Azrai, M., M.J. Mejaya, and H.G.M. Yasin. 2007. Breeding of Specialty Maize. In: Maize: Production Techniques and Development. http://balitsereal.litbang.pertanian.go.id/ ind/images/stories/tujuh.pdf (in Indonesian).

2. Bethlenfalvay, G.J., M.G. Reyes-Solis, S.B. Camel, and Eerrera-Cerrato. 1991. Nutrient transfer between the root zones of soybean and maize plants connected by a common mycorrhizal mycelium. Physiol. Plantarum, 82: 423-432. 
3. Fergason, V. 2001. High amylose and waxy corns. In: A.R. Hallauer (Ed), Specialty Corns. 2nd Edition. CRC Press LLC, Boca Raton, Florida, USA.

4. Ghosh, P.K., M.C. Manna, K.K. Bandyopadhyay, Ajay, A.K. Tripathi, R.H. Wanjari, K.M. Hati, A.K. Misra, C.L. Acharya, and A.S. Rao. 2006. Interspecific Interaction and Nutrient Use in Soybean/Sorghum Intercropping System. Agronomy Journal, 98: 1097-1108.

5. Gwirtz, J.A., and M.N. Garcia-Casal. 2014. Processing maize flour and corn meal food products. Annals of New York Academy of Science, 1312: 66-75.

6. Hamel, C., C. Nesser, U. Barrantes-Cartin, and D.L. Smith. 1991. Endomycorrhizal fungal species mediate $15 \mathrm{~N}$ transfer from soybean to maize in non-fumigated soil. Plant and Soil, 138: 41-47.

7. Inal, A., A. Gunes, F. Zhang, and I. Cakmak. 2007. Peanut/maize intercropping induced changes in rhizosphere and nutrient concentrations in shoots. Plant Physiology and Biochemistry, 45: 350-356.

8. Rashid, M.T., P. Voroney, and G. Parkin. 2005. Predicting nitrogen fertilizer requirements for corn by chlorophyll meter under different $\mathrm{N}$ availability conditions. Canadian Journal of Soil Science, 85: 149-159.

9. Sinclair, T.R., and C.T. de Wit. 1975. Photosynthate and nitrogen requirements for seed production by various crops. Science, 189: 565-567.

10. Ullah, I., M. Ali, and F. Farooqi. 2010. Chemical and Nutritional Properties of Some Maize (Zea mays L.) Varieties Grown in NWFP, Pakistan. Pakistan Journal of Nutrition, 9(11): 1113-1117.

11. Wangiyana, W., and I.G.M. Kusnarta. 1998. Increasing $\mathrm{N}$ uptake and yield of waxy maize of Bima local variety through intercropping with various types of legume crops. J. Penelitian Univ. Mataram, 14(1): 41-49 (text in Indonesian).

12. White, P.J. 2001. Properties of corn starch. In: A.R. Hallauer (Ed), Specialty Corns. 2nd Edition. CRC Press LLC, Boca Raton, Florida, USA.

13. Yilmaz, S., M. Atak, and M. Erayman. 2008. Identification of advantages of MaizeLegume intercropping over solitary cropping through competition indices in the East Mediterranean Region. Turkish Journal of Agriculture and Forestry, 32: 111-119.

14. Zingore, S. 2011. Maize Productivity and Response to Fertilizer Use as Affected by Soil Fertility Variability, Manure Application, and Cropping System. Better Crops, 95: 4-6. 